\section{Beyond nine lives}

A new company is trying to ensure that Fido and Fluffy will be around forever. Genetic Savings and Clone (GSC; College
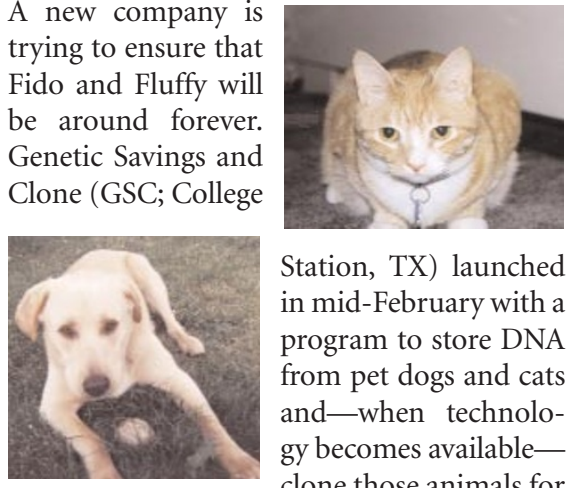

Station, TX) launched in mid-February with a program to store DNA from pet dogs and cats and-when technology becomes availableclone those animals for their owners. The company is a commercial spin-off from the Missyplicity Project at Texas A\&M University-a $\$ 2.3$ million dog-cloning effort funded by an anonymous wealthy pet owner whose dog, Missy, is getting on in years (Nat. Biotechnol., 16, 892). There is a parallel cat-cloning project called Operation CopyCat. The company will not give numbers on how many people have requested DNA storage for their pets, but Lou Hawthorne, CEO of GSC, claims response has been beyond the company's projections by an order of magnitude, and that GSC has also received inquiries about investment or merger opportunities. Hawthorne says he expects to see Missy clones sometime this year, after which GSC will offer dog cloning to customers "immediately." Cat cloning is on a similar basis. GSE expects the price for cloning will drop to $\$ 25,000$ within three years. JG

\section{Transatlantic biotech deal}

At the start of March, Cambridge Antibody Technology (Cambridge, UK) announced a 10-year, \$67 million agreement with genomics company Human Genome Sciences (Rockville, MD) to turn human genome data into human antibody-based therapies and diagnostics. Under terms of the deal, HGS will pay at least $\$ 12$ million to CAT in research funding and licensing fees for the right to use CAT's phage display technology in developing drugs from proteins HGS has derived from human genome sequence information. HGS will also pay $\$ 55$ million for a $6 \%$ stake (1.67 million shares) in the company and will make additional milestone and royalty payments on resulting products developed and sold by HGS. CAT has the right to develop a maximum of 24 of HGS's protein targets, and HGS can choose to share the costs and profits of 18 of those. The news sent CAT's stock shooting up around $60 \%$ to over $\mathfrak{E} 37(\$ 55)$ the day of the announcement, while HGS's share price rose $3.2 \%$ to $\$ 225.3$.

\section{Population genetics deal}

In mid-February, Gemini Holdings (Cambridge, UK) announced an agreement with Lineage Biomedical (St. John's, Newfoundland) to establish a joint venture, Newfound Genomics, to look at how genes affect the propensity to diseases common in Newfoundland's relatively homogenous population. Diseases may include psoriasis, rheumatoid arthritis, and osteoporosis. Essentially Newfound Genomics will recruit volunteers (who either have a disease or are at risk), and collect pedigree, clinical information, and tissue samples under informed consent. Very large-scale, rapid, high-resolution association studies or traditional linkage studies of all the information will be performed to discover genes associated with a disease. Gemini will be able to validate and explore the roles of the genes identified in Newfoundland in other populations, says Paul Kelly, Gemini's CEO. While financial details have not been disclosed, Gemini will contribute the clinical protocols, sample handling, bioinformatics and information management know-how. Newfoundlanders stand to gain expert diagnosis, assessment, and treatment where possible, as well as the creation of jobs and a stateof-the-art genomics and genetics research center. In addition, a $1 \%$ "net royalty" on whatever comes out of the research will go into a charitable trust for the population. $E D$

\section{Stem cells as research tools}

A nonprofit institute recently established at the University of Wisconsin (Madison, WI) plans to widely distribute human embryonic stem cells to qualified researchers in academia and industry. The WiCell Research Institute is a subsidiary of the Wisconsin Alumni Research Foundation (WARF), a private corporation that manages the university's intellectual property and holds the patents that govern the technology and use of the cells: "Immortal" embryonic stem cell lines were first successfully created by biologist James Thomson's UW lab in November 1998 - an announcement that set off a flurry of debate over whether government money should support research involving cells from human embryos (Nat. Biotechnol., 17, 11). As it stands, researchers cannot use federal funds for such research until guidelines from the US National Institutes of Health (Bethesda, $\mathrm{MD})$ are in place. Thomson's human embryo research was funded by Geron (Menlo Park, CA), and according to Carl Gulbrandsen, WARF's managing director, other groups will be able to use the cells only for research, not commercial, purposes. Any group that receives the cells will be required to follow strict guide- lines prohibiting intermixing of other species with the human cells or creation of embryos from the cells. Academic researchers will receive the cells for a one-time payment of $\$ 5000$, but Gulbrandsen says charge for industry will be "much higher." $J G$

\section{Japan bans human cloning}

Japan's Science and Technology Agency (Tokyo) has released draft legislation that prohibits the use of cloning techniques for human reproductive purposes. It also bars implantation of chimeric embryos-consisting of human and animal cells-into human or animal uteri for reproductive purposes. However, because of the potential medical applications-particularly those related to stem cell research - the use of these techniques in human embryo research would not be regulated by law but instead by means of guidelines. Offenders will be subject to heavy penalties, such as a prison sentence that would "reflect the severity of human cloning as a criminal act," according to an official from the agency. The draft legislation has been approved by the cabinet and the ruling Liberal Democratic Party and is therefore almost certain to be enacted as law during the current parliamentary session ending in June.

AS

\section{EPO admits patent mistake}

In late February, the European Patent Office (EPO; Munich, Germany) admitted a mistake in a patent issued last December for a technology that could include cloning of humans. The English version of the patent, which was issued to Edinburgh University and biotech company Stem Cell Sciences (SCS; Melbourne, Australia), did not include the word "nonhuman" in reference to cloning animal cells. The problem was first reported by environmental group Greenpeace, and there were none associated with the French and German language versions of the patent, which covers a method of isolation, selection, and propagation of transgenic stem cells. EPO said it "admitted this error and regrets that it has occurred. . .[and] will take every care to prevent such errors recurring in the future." However, by law EPO is not able to amend the current patent. Under the European Patent Convention, anyone may challenge the patent by filing an opposition within nine months from when the patent was granted, and EPO said it expects that to happen. Meanwhile, SCS has released a statement stressing that it never intended to use its patented technique to produce genetically engineered humans and says it has contacted EPO to confirm that position. JG 